\title{
Human Education towards Goodness. The Potential of the Kantian Concept of "Perpetual Peace" in Shaping Future Peaceful Relations among Nations
}

\author{
Zdzisław Kieliszek \\ Ph.D., Associated Professor, University of Warmia and Mazury in Olsztyn \\ (Olsztyn, Poland) \\ E-mail: zdzislawkieliszek@onet.pl \\ https://orcid.org/0000-0002-0723-5422
}

\begin{abstract}
Immanuel Kant is the author of the project of "perpetual peace" as a concept for a global federation of states remaining in peaceful relations towards each other. According to the philosopher, in order for such a federation to be possible at some time in the future, individual states need to be institutions which respect their citizens' right of self-determination. An additional necessary condition for the future implementation of "perpetual peace" is the appearance of at least one state with a republican system of government. The German thinker saw that as the first step towards realising "perpetual peace". According to Kant, "perpetual peace" is not only limited to the existence of a certain set of institutions, appropriate laws, or external relations among states and individual people. "Perpetual peace" chiefly demands that people internalise the following obligations: 1. peaceful conduct towards others; 2. hospitality; 3. fairness; 4. respect towards the self-determination of others; 5. self-sufficiency; 6 . respecting the freedom of others; 7. refraining from actions which might raise distrust in others. Based on those requirements, the philosopher suggests that the fundamental condition for a future existence of "perpetual peace" is the proper moral education of people.

Keywords: Immanuel Kant, "perpetual peace", human, human obligations, education, future peaceful international relations
\end{abstract}

Received: March 28, 2019; accepted: May 3, 2019

Philosophy and Cosmology, Volume 24, 2020: 151-158.

https://doi.org/10.29202/phil-cosm/24/15

\section{Introduction}

In the search for possible solutions to the current challenges faced by humanity, and also those which could be posed in the foreseeable future, it always seems prudent to reach to the thought of time-honoured authors. It would be an error to reject their heritage solely for the reason that they lived in different circumstances and the given challenges were completely unknown to them and, hence, one would not expect to find anything valuable

(C) Kieliszek, Zdzisław, 2020 
in their deliberation in the context of our current and foreseeable problems. As it turns out, the achievements of many thinkers of distant times contain useful potential for adequately addressing the existing or expected challenges of contemporary life. For example, the thought of Immanuel Kant is helpful in one area currently undergoing lively debate, that of copyright protection (Kieliszek, 2016: 9-23). The works of another great German philosopher, Johann G. Fichte, is pertinent in the solving of problems brought on by the modern process of globalisation (Kieliszek, 2018: 83-91).

Among the many challenges faced by humanity at present, one of the most pressing is without a doubt the question of conditions, which would increase the likelihood of future peaceful relations among nations. And so - reflecting the conflict between the adherents of liberalism and communitarianism - one of these conditions seems to be the recognition of the ontic-functional status of the nation as a natural community, which guarantees the protection of an individual's freedoms, and allows an individual to achieve fulfilment as a social being (Kieliszek, 2017: 9-20). The search for other conditions necessary for a future global peace leads one to analysing, among others, the works of Immanuel Kant. This author's formulation of the influential concept of "perpetual peace" laid the foundations for the creation of such important international organisations as the United Nations and the European Union (Świrska-Czałbowska, 2005: 70; Przyłębski, 2011: 105-118). Furthermore, Kant — similarly to Thomas R. Malthus — was realistic in his assessment that a complete and enduring elimination of conflict among people is not possible, even if the conditions were met in the future for peaceful shaping of human interactions (Kieliszek, 2019: 1-10). We may therefore expect in Kant's work some interesting recommendations for what should lie at the centre of humanity's interests if we aim to successfully decrease the number of international conflicts in the future, while simultaneously respecting human liberty.

Crucial to the discernment of this potential in the enormous heritage of Kant is noting the import of his distinction between culture and civilisation. Far from being just another nicety in Kant's thought, this distinction sheds light on the idea of "perpetual peace", allowing us to capture its depth and potential for shaping future relations between nations to be as peaceful as they can possibly be.

The intention outlined above determines the course of the present discussion. Firstly, Kant's idea of "perpetual peace" will be briefly described. The distinction between culture and civilisation will then be outlined, as proposed by the German philosopher. Subsequently, the Kantian concept of "perpetual peace" will be presented in the light of this distinction; specifically, it will be shown that the order of "perpetual peace" has two "strata", those being the cultural stratum and the civilizational stratum and, furthermore, that it rests on a foundation of specific moral values. In the later course of the paper, the Kantian concept of human education towards goodness will be outlined. Finally, the potential of Kant's thought for the future shaping of the international order in peaceful ways will be presented.

\section{An outline of Kant's idea of "perpetual peace"}

The Kantian concept of "perpetual peace" presents a vision of a world-wide federation of states with republican systems of government, which remain in stable peaceful relations with one another (Kant, 2011: 447-448). According to Kant, the formation of this global federation should be the constant goal of humanity (Kant, 2011: 454-459). In turn, the initiation of the process leading to "perpetual peace" would be the creation of the first state with a republican system of government. Kant postulated that this first republic would "infect" other states with 
its governmental system, beginning with its neighbours, which would eventually lead to the global federation of states and the inception of "perpetual peace" (Kant, 2012a: 345).

The philosopher postulated that the rules of a republican order are liberty, equality and equal standing under the law for all citizens. A republic has the most desirable form of social organisation for countries, since it is a system, which respects human self-determination. Furthermore, in a republic, citizens are treated as both the means and the goal of a society's existence, and they treat their own interests on a par with those of others and of the community as a whole. Finally, according to Kant, a state with a republican system of government is a just state (Kant, 2012a: 339-340).

For analogous reasons, an association of republican states into a federalist-type union is considered by Kant to be a desirable form of international order, since it is an order based on the freedom, equality and the subjection of member states to equal laws. Individual members of a federal union have a completely equal status, which enables the just conduct of their mutual relations (Kant, 2011: 448-449). Furthermore, a federation guarantees the independence of each country, and its interests are treated by other countries on a par with their own, and those of the whole union (Kant, 2012a: 356).

\section{Kantian distinction between culture and civilisation}

Kant's thinking is characterised by many distinctions, many of which have a dichotomous character. The most famous of these are such pairs of terms and entities as: 1. a priori and $a$ posteriori; 2 . phenomenon and noumenon; 3 . analytic propositions and synthetic propositions; 3. senses and intellect; 4. time and space; 5 . morality and legality.

On the other hand, the distinction made by the philosopher from Königsberg between culture and civilisation is raised only on rare occasions. Meanwhile, it is quite a consequential distinction, if only because of how typical this understanding and presentation of culture and civilisation became in German philosophy (Botz-Bornstein, 2012: 17-18; Tarasiewicz, 2011: 80-81). Furthermore, it sheds light on Kant's concept of "perpetual peace", allowing one to see that it is, at its core, a moral project.

As described above, Kant had a profound impact on the establishment of the distinction between culture and civilisation, typical for the later German literature. It is worth noting, that this distinction was not adopted in the francophone and English language traditions, where the two terms are, for the most part, used interchangeably. Both terms are used by non-German scholars to denote the material artefacts of human construction, the set of social institutions, and the entirety of external interpersonal relations, to the almost complete exclusion of the internal sphere of human life. Meanwhile, for the Germans, who have been shaped by Kantian intuitions, "culture" refers primarily to the internal sphere, while "civilisation" refers to the material effects of human activity, the system of social institutions, and the sphere of external human relations shaping a given community. The sphere denoted by "civilisation" is also perceived by the German thinkers as a reflection of the ideas, values, or convictions adopted internally by the members of the community (Skrzydlewski, 2001: 340; Krąpiec, 2005: 133).

According to Kant, the internal sphere of human life is essentially shaped in the process of education, or upbringing. This means that the way a given person is educated profoundly impacts the attitudes which will be adopted by them, what convictions they will hold and what use they will make of their freedom. In Kant's view, in the process of education, each person is enculturated, in the sense of being equipped with particular patterns of behaviour, convictions and values (Kant, 1999: 41; Kant, 2005: 299-300). 
In turn, benefiting from the material creations of human activity, social institutions, and external relations between people serves, according to Kant, to civilise a human being. The sphere of civilisation, in addition, makes manifest the internal values, convictions, and stances held by people (Kant, 2012: 34-35). One can therefore say that, in the Kantian understanding, culture is the ideological substrate of civilisation.

\section{Cultural and civilizational "stratification" of "perpetual peace"}

The distinction between culture and civilisation outlined by Kant allows one to see that the order of "perpetual peace" which he postulates, presents itself as "stratified", i.e. that it is composed of a cultural stratum and a civilizational one.

This means that the Kantian vision of a republic and of the global federation is not merely limited to the appropriate external organisation of given institutions, solutions or the outward relations between citizens and individual countries. The Kantian project of republic and federation also involves a substrate which can be identified as "culture", in the Kantian understanding of the term. In other words, "perpetual peace" does not only concern the sphere described by Kant as "civilisation", meaning the given set of institutions, laws and modes of cooperation between its entities (Kant, 2012: 35-36). The project also includes specific convictions, values and patterns of behaviour, which have been internalised by people (Kant, 2012: 40-41).

Furthermore, in the light of the Kantian distinction between culture and civilisation, one could say that the philosopher rested the outward organisation of the republic and the global federation on something internal to them, this being the very values, convictions and modes of behaviour which each person adopts as their own and which, in aggregate, are understood by the Kantian term "culture". In this light, the (internal) cultural substrate is primary with respect to the stratum of civilisation, organising the outward form of the republic and of the global federation in "perpetual peace" (Kant, 2012: 40).

It seems justified to say that according to Kant, the necessary condition for the realisation of "perpetual peace" is not so much the proper external organisation, regulating the interactions between the country's citizens, or between the participating countries, as it is a more internal adoption by people of proper convictions, values and patterns of behaviour (Kant, 2012a: 344-345). This poses the obvious question: what convictions, values and, specifically, patterns of behaviour (In Kant's terms - maxims, i.e. general moral rules of behaviour) would, in the opinion of the philosopher, lay the foundations for "perpetual peace"?

\section{Kant's vision for the moral foundations of "perpetual peace"}

According to Kant, the internal sphere of human life is generally regulated by four classes of moral duties: 1. perfect duties of a person towards oneself; 2. perfect duties towards others; 3. imperfect duties towards oneself; 4. imperfect duties towards others. All four classes regulate human behaviour by indicating what a person must do under any circumstances, and if they leave some latitude (imperfect duties), it is not in the sense of their operation being suspended, but only in giving a person a choice as to the way in which they will be satisfied (Höffe, 2003: 168-183).

In the light of Kant's heritage, one may say that among these four classes of duties, the realisation of "perpetual peace" (which is a project for regulating relations among people) rests first and foremost on perfect duties towards others. According to Kant, these are the only duties, which regulate human interaction and at the same time bind the individuals 
subject to them in equal and reciprocal ways. Other classes of duties seem secondary to the project of "perpetual peace", since they regulate the relation of a person to oneself, and thus do not concern interpersonal relations at all (as in the case of perfect and imperfect duties towards oneself); or, as in the case of imperfect duties towards others, in spite of concerning interpersonal relations, they do allow relative prioritising of certain areas of their operations versus other areas (depending on finite human abilities in the given circumstances), and thus are not equal and reciprocal in nature (Kant, 2011: 501-503, 533-538, 570-572).

Bearing in mind the above suggestions, as well as Kant's remarks on the general conditions for "perpetual peace", one might create the following catalogue of the moral duties (maxims) foundational to the order of "perpetual peace": 1. peaceful conduct of people towards each other; 2 . hospitality towards strangers; 3 . fairness towards others; 4 . respecting others' selfdetermination; 5. striving towards self-sufficiency, i.e. living at our own cost, and not that of others; 6. respect for others' autonomy; 7. strictly refraining from actions which might raise distrust in others (Kant, 2012a: 333-349). The adduced duties belong to the class of perfect duties towards others, since they regulate interpersonal interactions and they are equal and reciprocal for both parties.

The philosopher from Königsberg seems to be expressing the view that the condition for the realisation of "perpetual peace" is a peaceful, hospitable and fair conduct among people, while respecting others' self-determination and autonomy, striving for self-sufficiency, and cultivating trust. In other words, until these patterns of behaviour become ubiquitous among people, "perpetual peace" will remain nothing but a dream. In consequence, we now reach the question of the Kantian project of popularising proper behaviours in people.

\section{Kant's concept of human education towards goodness}

According to Kant, a human being differs from the animals by being born not fully formed. A new-born human is equipped with merely the seeds of humanity, and requires not only feeding and care but, just as importantly, the help of other people, e.g. those with more life experience, in developing his or her own humanity to the fullest. Hence, in his work On Pedagogy, the philosopher postulates that a human being should be exposed to four external influences during development: 1 . the practice of discipline and obedience; 2 . teaching various practical skills; 3. civilising; 4. moral education (Kant, 1999: 41-50).

The first of the mentioned influences is intended to harness the natural human wildness and the tendency to act in ways harmful to the individual and the society at large. According to Kant, discipline consists primarily in negative interaction with the pupil, since it involves various forms of coercion from the pedagogues. The second influence serves to equip the individual with skills, such as reading and writing, which will be helpful in reaching goals and performing tasks. The third interaction is intended to socialise the individual, to prevent them from committing illegal acts, to allow them to garner respect and sympathy, and to display good manners. Finally, the fourth interaction should direct the individual to select good goals in life, i.e. such that could be considered worthy and morally valuable by anyone. Especially, individuals should be taught to fulfil perfect and imperfect moral duties towards themselves and others. The common goal of all four influences is to bring an educated individual as close as possible to the ideal of human perfection.

The philosopher noted that should the process of education be limited to only the first three of these four influences, human beings might be with relatively little effort trained similarly to animals, i.e. to have mechanically inculcated in them what should be done in a given situation for the actions to be harmless or beneficial for the individual and others, as 
well as socially acceptable. But that condition of a human being would still be undesirable, since the person would not be using their own reason, following internally accepted maxims, but would only obey externally imposed rules of behaviour (Kant, 1999: 50). Crucial in the formation of humanity in a person is, according to Kant, the fourth influence, because it releases, in concert with the other three pedagogical influences, the capacity within a human being for a rational and maxim-driven use of their own freedom. One could say that Kant views moral instruction as decisive in the success of the educational process, while the other areas have a secondary importance (Kant, 1999: 54-55).

In his analysis of moral instruction, Kant observed that utmost care should be taken to eliminate in pupils vices such as, e.g. jealousy, ingratitude, satisfaction at the misfortune of others, meanness, unfaithfulness, squandering of wealth and health, disrespect for others, stinginess, sloth and lack of compassion. On the other hand, one should cultivate in them virtues such as: diligence, fairness, peaceful disposition, temperance, magnanimity, charity, and self-control. According to Kant, the first three of these are especially important, since they belong to the so-called virtues of duty, i.e. they are consistent with perfect and imperfect duties towards oneself and others. This means that, unlike virtues of merit (e.g. magnanimity, charity, self-control) and virtues of innocence (e.g. temperance), the virtues of duty are a necessary condition of moral uprightness, since they indicate what a human being must be like to be considered morally good at all. Virtues of merit and of innocence, meanwhile, are only an "addition", elevating the individual to even higher levels of goodness (Kant, 1999: 79-91).

Among many practical indications offered by the philosopher regarding the process of moral instruction, a noteworthy suggestion is that from the earliest age pupils should learn to use their freedom in such a way so as not to harm themselves or others. As the child grows up, the requirements in this matter should be systematically raised (Kant, 1999: 53-54). Kant also recommends that in the process of moral instruction one should avoid both punishment and reward, especially excessive, since that will lead to self-interested and inauthentic stances in the pupil, instead of leading to the love of goodness for its own sake. A good way for the pedagogue to inform the pupil whether their conduct is moral or not would be approval in the first case, and disapproval in the second (Kant, 1999: 79-82). Furthermore, since the process of moral instruction is one of the most difficult undertakings, Kant demanded that the instruction of the next generation be entrusted to experts, rather than random people (Kant, 1999: 49). In turn, the experts themselves should rather inspire young people with the example of their own lives, than merely instruct them to behave well with theoretical moralising or harsh discipline (Kant, 1999: 52). Kant's proposition of creating the "moral catechism" is also worth discussing. The philosopher postulated curating examples of situations explaining the moral course of action, with the expectation that as little as one hour is reading a day would make great strides towards moral edification of the populace (Kant, 1999: 89-90. The thinker also suggested that education should continue until a child turns 16 , since this is the time when a person is most "malleable", i.e. responsive to external influences of the pedagogues. For older individuals, other means are indicated, such as watching performances of literary plays, or reading particular books, as well as the indirect education by the proper sanctions of the positive law. However, moral instruction of adults - according to Kant can no longer be as direct as in the case of children and adolescents (Kant, 1999: 53).

In Kant's view, the principal task of education is the formation of a human being in such a way that they consistently act according to appropriate maxims and, in particular, that they fulfil moral duties. This process should, then, lead people to become diligent, fair, and peaceful towards others. This leads one to conclude that, according to the philosopher, the 
realisation of "perpetual peace" is directly contingent on subjecting subsequent generations to the proper educational process and popularising desired behaviour patterns among the people.

\section{Conclusions}

Based on the discussion above, it is possible to conclude that Kant felt that the best way to achieve the fullest peaceful relations among people depended on proper moral education. The philosopher seems to suggest that the education of future generations towards goodness needed to be treated as a cornerstone in the realisation of "perpetual peace". In other words, if "perpetual peace" is to ever become a reality, it will not be merely as a result of appropriate political or economic agreements, or military solutions, but thanks to the educational elevation of human morality to the proper level.

Following Kant's intuitions in this regard, one could postulate that among the many initiatives undertaken by various state, regional, international, and global institutions in their efforts towards peace, initiatives for moral education must not be overlooked. In the future, constant care must be taken to promote among people the dispositions of peaceful coexistence, hospitality towards outsiders, fairness, respect for the self-determination of others, self-sufficiency, respect for others' freedom and the inclination to foster mutual trust. Those future initiatives may take the form of properly profiled national educational programs in schools, academic conferences or films presenting appropriate contents.

This proposal seems especially timely now, since distrust of outsiders, noticeable in the context of the continuing waves of migrants arriving in Europe, breeds feelings of constant threat and uncertainty in many people, which in turn often leads them to become callous or even aggressive towards others. It is also easy to see the extent of cruelty and mercilessness that contemporary people are capable of. It is still not uncommon for a nation to attempt to subjugate another nation, or even to attempt to eradicate it. Furthermore, nowadays people sorely lack moral authorities and role models worthy of emulation. Finally, in the light of Kantian thought, one might fear that a significant threat to peaceful relations among people is the noticeable disarray of moral systems in the world, widespread consumerism and the focus of people merely on material, short-term gains.

\section{$\mathbb{E}[\mathbb{\text { References }}$}

Botz-Bornstein, Thorsten. (2012) What is the Difference between Culture and Civilization? Two Hundred Fifty Years of Confusion. Comparative Civilizations Review, 66: 10-28. Huffe, Otfried. (2003) Immanuel Kant. Translated by Andrzej Maciej Kaniowski. Warszawa. Kant, Immanuel. (2005) Antropologia w ијксіи pragmatycznym [Anthropology in Pragmatic Terms]. Translated by Ewa Drzazgowska and Paulina Sosnowska. Warszawa.

Kant, Immanuel. (2012) Idea powszechnej historii w aspekcie kosmopolitycznym [The Idea of Universal History in a Cosmopolitan Aspect]. Translated by Mirosiaw Ïelazny. In Immanuel Kant Dzieia zebrane [Collected Works], Vol. 6, Toruc, 2012: 29-44.

Kant, Immanuel. (2012a) Ku wieczystemu pokojowi [Towards the Eternal Peace]. Translated by Mirosiaw Ïelazny. In Immanuel Kant Dzieia zebrane [Collected Works], Vol. 6, Toruc, 331-374.

Kant, Immanuel. (2011) Metafizyka moralnoњci [Metaphysics of Morality]. Translated by Wiodzimierz Galewicz. In Immanuel Kant Dzieia zebrane [Collected Works], Vol. 5, Toruc, 289-622. 
Kant, Immanuel. (1999) O pedagogice [About Pedagogy]. Translated by Dorota Sztobryn. Jydџ.

Kieliszek, Zdzisiaw. (2016) The Timeliness of Kant's Vision of Copyright. Studia Warmicskie, Vol. 53: 9-23.

Kieliszek, Zdzisiaw. (2019) Future Conflicts Are Inevitable: Causes of Interpersonal Conflicts According to Immanuel Kant and Thomas R. Malthus. Philosophy and Cosmology, Vol. 22: 152-162. https://doi.org/10.29202/phil-cosm/22/14

Kieliszek, Zdzisiaw. (2018) National Identity as an Important Topic of the Research on the Man in the Future: "Opening" the Potential of the Fichtean Concept of National Identity. Philosophy and Cosmology, Vol. 20: 83-91. https://doi.org/ 10.29202/phil$\operatorname{cosm} / 20 / 7$

Kieliszek, Zdzisiaw. (2017) Ontological-functional Status of the Nation and the Basic Ideas of Liberalism and Communitarianism. Studia Warmicskie, 54: 9-20.

Krapiec, Mieczysiaw Albert. (2005) Kultura [Culture]. In Andrzej Maryniarczyk (ed.), Powszechna encyklopedia filozofii [Universal Encyclopedia of Philosophy], Vol. 6, Lublin, 132-138.

Przyiкbski, Andrzej. (2011) Duch czy ïycie? Studia i szkice z filozofii niemieckiej [Spirit or Life? Studies and Sketches from German Philosophy]. Poznac.

Skrzydlewski, Pawei. (2001) Cywilizacja [Civilization]. In Andrzej Maryniarczyk (ed.), Powszechna encyklopedia filozofii [Universal Encyclopedia of Philosophy], Vol. 2, Lublin, 339-348.

Њwirska-Czaibowska, Karolina. (2005) Koncepcje Wspylnej Europy na przestrzeni wiekyw [Concepts of Common Europe over the Centuries]. Studia i Materiaiy - Wydziai Zarz№dzania UW, Vol. 1: 69-74.

Tarasiewicz, Pawei. (2011) „Kultura” i „cywilizacja” — pryba korelacji [“Culture” and "Civilization" — an Attempt to Correlate]. Roczniki Kulturoznawcze, 2: 71-88. 